\title{
FENOMENOLOGI SUMBER DAYA MANUSIA SEBAGAI ASET INTELEKTUAL DALAM AMAL USAHA MUHAMMADIYAH
}

\author{
Irman Mamulati \\ Iwan Triyuwono \\ Aji Dedi Mulawarman \\ Universitas Muhammadiyah Maluku Utara \\ Jln. KH. Ahmad Dahlan No. 100 Ternate \\ Universitas Brawijaya \\ J1. MT Hariyono 165 Malang \\ Email: irmanmamulaty@gmail.com
}

Abstract

Human Resource Phenomenology As The Intellectual Assets in Amal Usaha Muhammadiyah. Research is aimed to disclose the meaning of human resource as the intellectual assets. The approach of research is qualitative whereas the method is phenomenological interpretive. Result of research indicates that the intellectual assets in Amal Usaha Muhammadiyah are signified as the disseminator of knowledge and the driver of dakwah, income source and also expense.

Keywords: human resource, intellectual assets, the disseminator of knowledge, the driver of dakwah, income source, expense, amal usaha muhammadiyah, phenomenology

Abstrak

Fenomenologi Sumber Daya Manusia Sebagai Aset Intelektual dalam Amal Usaha Muhammadiyah. Penelitian ini bertujuan untuk menggungkap makna sumber daya manusia sebagai aset intelektual. Penelitian ini menggunakan pendekatan 
kualitatif dengan metodenya adalah interpretif fenomenologi. Hasil penelitian menujukkan bahwa aset intelektual dalam Amal Usaha Muhamadiyah dimaknai sebagai penyebar ilmu dan penggerak dakwah, sumber pendapatan, dan beban.

Kata kunci: sumber daya manusia, aset intelektual, penyebar ilmu, penggerak dakwah, sumber pendapatan, beban, amal usaha muhammadiyah, fenomenologi

\section{PENDAHULUAN}

Sampai saat ini Sumber Daya Manusia (SDM) masih menjadi perdebatan hangat dikalangan akademisi maupun para praktisi akuntansi. Hal tersebut disebabkan manfaat yang diberikan kepada organisasi tempat ia bekerja. Bahkan dengan SDM organisasi tersebut dapat berkembang, dan juga sebaliknya. Akan tetapi pada akhirnya SDM diposisikan dalam akuntansi sebagai beban bagi organisasi. Oleh karenanya, praktik akuntansi yang kapitalis telah membudaya dikalangan masyarakat, sehingga yang menjadi sorotan adalah beban akibat keberadaan SDM, bukan sebaliknya.

Perdebatan tersebut diakibatkan SDM yang merupakan aset intelektual sulit untuk diukur secara nominal, akan tetapi pengetahuan dan kemampuannya dipandang sebagai pencipta nilai. Dalam konteks ini SDM merupakan aset terbesar dimana pengetahuan dalam diri mereka adalah merupakan aset yang sebenarnya. Tentunya, hal ini bukan merupakan sesuatu hal yang baru karena sesungguhnya pengalaman dan skill selalu menjadi fondasi utama dalam sebuah organisasi (Lank, 1977).

Menurut Singh (2009) pengetahuan atau skill yang dimiliki oleh perusahaan lebih kaya makna, lebih berarti dibandingkan dengan aset fisik maupun aset keuangan. Karena intelektual, pengalaman, pengetahuan, sikap, kejiwaan, pendidikan, perilaku dan sistem nilai dari tenaga kerja sebagai sumber daya manusia dapat meningkatkan efisiensi atas produksi atau penyedia jasa dan menciptakan kemakmuran tertentu bagi organisasi. Manusia adalah makhluk yang memiliki kreatif dan inovatif yang berusaha untuk mencapai hasil maksimal.

Para peneliti di bidang sumber daya manusia meyakini bahwa aset tidak berwujud adalah sumber daya manusia itu sendiri dan akan sangat mungkin menjadi bagian penting dalam neraca dimasa depan dalam proses pengembangan teori akuntasi. Pada era berbasis pengetahuan, studi informasi akuntansi untuk sumber daya manusia adalah total nilai yang dihasilkan dari biaya yang diinvestasikan perusahaan yang dapat direalisasikan dalam bentuk nilai tambah kepada perusahaan (Yanping dan Wang, 2005).

Manusia tidak bisa dikatakan sebagai manusia jika dinilai sebagai variabelvariabel terukur secara terpisah, karena manusia sendiri merupakan aset perusahaan yang memiliki kontribusi terbesar bagi perusahaan. 
In the business enterprise, a well-organized and loyal personal may be a more importent "asset" than a stock of merchandise, At present there seems to be no way of measuring such factors in terms of the dollar (Rodhe, dkk, 1976).

Berdasarkan konsep bahwa SDM merupakan aset yang paling terpenting baik dalam organisasi bisnis maupun sosial, personil yang loyal di anggap sebagai aset yang paling penting dibandingkan dengan stok barang dagang. Karena SDM mampu memberikan manfaat melebihi manfaat dari yang dapat diberikan oleh sumber daya material. Namun Rhode (1976) menyadari tidak terdapat cara untuk mengukur SDM dalam nilai dolar seperti aset fisik lainnya. Jika kita kembali pada Standar Akuntansi Keuangan (IAI, 2009: No 16 dan 19) yang berkaitan dengan konsep aset, maka aset dibagi menjadi dua bagian yaitu aset tetap dan aset tidak berwujud. Aset tetap terdiri dari tanah, bangunan, mesin, uang, kendaraan, dll. Sementara aset tidak berwujud berkaitan dengan merek hak paten, hak cipta, dll. Selain itu, untuk dapat diatakan sebagai aset harus memiliki beberapa kriteria agar dapat diakui sebagai aset, baik yang sifatnya aset tetap maupun aset tidak berwujud. Menurut Financial Accounting Standar Board (FASB) sebagaimana diterjemahkan Suwarjono (2006:252) aset merupakan manfaat ekonomi masa mendatang yang cukup pasti yang diperoleh atau dikuasai/dikendalikan oleh suatu entitas sebagai akibat transaksi atau kejadian di masa lalu. Hal serupa juga diungkapkan oleh International Accounting Standards Committe (IASC, 1997), yaitu: "an asset is resource controlled by the enterprise as a result of past events and from which future economic benefits are expected to flow to the enterprise.

Kriteria yang digagas FASB dan IASC berkaitan dengan aset, maka SDM dapat dikatakan sebagai aset tidak berwujud. Hal tersebut disebabkan manfaat yang diberikan SDM terhadap perusahaan dimana tempat ia bekerja. Penjabaran di atas merupakan bentuk pengakuan aset intelektual yang diakui sebagi asset tidak berwujud di organisasi yang berorientasi kepada profit (profit oriented)maupun non profit oriented. Perbedaan ini dimungkinkan terjadi karena value basic yang mendasari interaksi bisnis maupunn non bisnis di masing-masing organisasinya. Aset intelektual akan dimaknai sebagai beban karena memang substansi aturan tersebut beredar dalam budaya kapitalis yang mengakui SDM sebagai mesin untuk menghasilkan laba (Setiabudi dan Triyuwono, 2002:100). Jika organisasi didasari oleh nilai-nilai Islam maka sudah barang tentu aset intelektual akan memiliki makna sangat mencirikan nilai-nilai tersebut.

Penelitian ini dilakukan di organisasi Islam yang bergerak dalam bidang pendidikan yaitu Amal Usaha Muhamadiyah. Di dalam organisasi Amal Usaha Muhamadiyah, SDM merupakan salah satu pilar penggerak organisasi. SDM bagi Amal Usaha Muhammadiyah dapat dikatakan sebagai aset intelektual. SDM bagi pendiri Muhamadiyah yaitu KH. Ahmad Dahlan merupakan motor penggerak 
pencapaian tujuannya yaitu amar ma'ruf nahi munkar sebagaimana yang tertuang dalam Surat Al-Imran ayat 104. Dengan demikian, perbedaan tujuan organisasi akan menghasilkan pemaknaan yang berbeda pula

Sepengetahuan penelitian, belum ada penelitian tentang makna aset intelektual di organisasi Islam. Namun, terdapat penelitian serumpun yang memaknai aset secara umum seperti Wulandari (2012), yaitu mengungkap makna pemain sepak bola sebagai aset bergerak komersial, aset non-keuangan, dan aset sosio-ekonomis yang semuanya dalam konteks pemain sebagai aset klub PT. Arema Indonesia. Widati (2011) juga melakukan penelitian pada organisasi Aisyiyah Kota Malang yang menjabarkan makna yang terdiri atas aset ekonomi, mental dan spritual. Hal yang serupa juga dilakukan oleh Luayyi (2012) pada Pondok Pesantren. Hasil penelitiannya menemukan makna aset terdiri atas aset lahiriyah yaitu aset ekonomi dan aset batiniyah yaitu aset mental dan spritual.

\section{METODE PENELITIAN}

Penelitian ini merupakan penelitian yang dilakukan dalam ranah kualitatif. Penjelesan tentang penelitian kualitatif sebagaimana dijelaskan Smith (2009:48) sebagai penelitian yang mempelajari suatu bidang antar disiplin, lintas disiplin bahkan terkadang merupakan lawan disiplin dari suatu fenomena yang terjadi. Penelitian kualitatif dapat menghubungkan ilmu pengetahuan humaniora, sosial dan sains modern yang menyebabkan penelitian ini dapat menyentuh semua sudut pandang pemikiran penulis yang ingin mengeksplorasi ide secara lebih bebas dan membumi. Menurut Sukuharsono (2006) penelitian kualitatif dapat menggunakan beberapa metode untuk menjawab penelitian. Akibatnya, secara idial dalam melakukan riset kualitatif memerlukan "a strong commitment to study a problem" dan :demands time and resoursces".

Metodologi penelitian kualitatif merupakan prosedur penelitian yang menghasilkan data diskriptif berupa kata-kata tertulis atau lisan dari orang-orang, dan perilaku yang dapat diamati, yang dipusatkan pada pengalaman individu secara utuh (Bogdan dan Taylor, 1993:5). Moleong (2006:6) juga menegaskan penelitian kualitatif adalah prosedur yang menghasilkan data-data diskriptif, yang meliputi kata-kata tertulis atau lisan dari orang-orang untuk memahami objek penelitian yang sedang dilakukan, tentunya harus didukung dengan studi literatur berdasarkan pendalaman kajian pustaka, baik berupa data penelitian, maupun angka yang dapat dipahami dengan baik.

Dalam penelitian ini penulis menggunakan metode interpretif fenomenologi sebagai pijakan dalam memahami SDM sebagai aset intelektual dalam Amal Usaha Muhammadiyah yaitu Universitas Muhammadiyah Maluku Utara. Menurut Burrell dan Morgan (1979:227) paradigma interpretif meliputi cakupan yang luas atas gagasan filosofis dan sosiologi yang memberikan karakteristik umum untuk mencoba 
memahami dan menjelaskan dunia sosial dengan tujuan utama untuk melihat pelaku yang secara langsung terlibat dalam proses sosial. Selain itu, paradigma interpretif menggunakan cara pandang para nominalis yang melihat realitas sosial sebagai sesuatu yang hanya merupakan label, nama, atau konsep yang digunakan untuk membangun realitas dan bukanlah sesuatu yang nyata, melainkan hanyalah penamaan atas sesuatu yang diciptakan oleh manusia atau merupakan produk manusia itu sendiri.

Audifax (2008:29) menambahkan dalam paradigma interpretif, penelitian sosial tidak selalu dan tidak secara langsung memilih nilai instrumental untuk sampai pada peramalan dan pengendalian fenomena sosial. Penelitian dilakukan untuk mengembangkan pemahaman. Penelitian membantu kita untuk mengerti dan menginterpretasi apa yang ada di balik peristiwa: latar belakang pemikiran manusia yang terlibat di dalamnya, serta bagaimana manusia meletakkan makna pada peristiwa yang terjadi. Paradigma interpretif, dalam banyak hal juga sering disebut sebagai paradigma konstruktif yang menekankan bahwa penelitian pada dasarnya dilakukan untuk memahami realitas dunia apa adanya (Denzin dan Lincoln, 2009:148).

Fenomenologi merupakan ilmu (logos) yang mempelajari tentang hal-hal yang tampak. Dalam bahasa Yunani phainesthai berarti “yang menampakan diri”. Apa yang menampakan diri? bisa macam-macam: perasaan, benda, peristiwa, pikiran, lembaga sosial dan seterusnya (Audifax, 2008:205). Fenomenologi, pada awalnya merupakan kajian filsafat dan sosiologi. Edmund Husserl sendiri, sebagai penggagas utama, mengingkan fenomenologi akan melahirkan ilmu yang lebih bisa bermanfaat bagi manusia, setelah sekian lama ilmu pengetahuan mengalami krisis dan difungsional. Fenomenologi, kemudian berkembang sebagai semacam metode riset yang diterapkan dalam berbagai ilmu sosial, termasuk didalamnya akuntansi, sebagai salah satu varian dalam penelitian kualitatif dalam payung paradigma interpretif.

Edmund Hussel berpendapat bahwa salah satu tujuan utama dari fenomenologi adalah hendak membumikan dasar-dasar pengetahuan secara radikal sehingga serangan skeptis terhadap rasionalitas dan prosedurnya dapat dihadapi. Untuk membangun basis yang aman bagi pengetahuan, Husserl memutuskan untuk memulai dengan permsalahan mengenal bagaimana objek dan peristiwa muncul dalam kesadaran (Giorgi dan Giorgi dikutip Smith, 2009:50). Secara sederhana, sesungguhnya dalam aktivitas yang kita lakukan, telah mempraktekan fenomenologi. Kita mengamati fenomena, kita membuka diri. Kita membiarkan fenomena itu tampak pada kita, lalu kita memahaminya. Kita memahaminya dalam prespektif fenomena itu sendiri, bagaimana ia bercerita terhadap kita.

Sebagaimana pendapat Brouwer (1984:3) seorang fenomenolog senang melihat gejala (fenomena). Melihat gejala merupakan dasar yang syarat mutlak untuk semua aktivitas ilmiah. Ia bukan ilmu tetapi merupakan cara pandang, metode penelitian, a way looking at things. Bagi Brouwer, fenomenologi tidak bisa hilang 
dan menjadi syarat mutlak bagi seseorang yang mau memikirkan dasar dari usaha ilmiah atau dasar dari hidupnya sendiri. Lebih jauh, fenonomenologi mengajarkan kita untuk membiasakan diri, tidak lagi melihat benda-benda, melainkan fenomena.

Dalam penelitian fenomenologi peneliti dituntut untuk agar mampu mendiskripsikan. Moustakas (1994) menjelaskan fenomenologi merupakan diskripsi pengalamanpengalaman. Artinya, untuk menggambarkan seakurat mungkin sebuah fenomena, sekaligus tetap menjaga keadaan sebenarnya seperti yang nampak pada diri informan. Sementara itu, suatu fenomena yang nampak mengandung unsur sosial dan psikologis (Welman dan Kluger, 1999).

Proses pengumpulan data dalam fenomenologi adalah tahapan pemahaman atas sesuatu dari sudut pandang informan (understanding the world from the subject point of view, to unfold meaning of peopleexperiences). Sehingga pemahaman tersebut kemudian diikuti dengan tahapan mengingat kembali (Groenewald, 2004:13).

Proses menggali dan mengumpulkan data dari informan dilakukan dengan menggunakan teknik wawancara secara mendalam dan peniliti sebagai partisipan. Data yang telah terkumpul dibuat kompilasi tematik, data dipilah-pilah kedalam sub-sub tema sesuai dengan tujuan penelitian. Termasuk pada tahap ini peneliti berusaha melakukan pemahaman ke dalam alam kesadaran subyek yang berupa aktivitas-aktivitas mengingat, meresapi, dan mengingini. Dimana ketiga jenis aktivitas kesadaran tersebut memiliki keterarahan pada "sesuatu" yang di dalam metodologi disebut intensionalitas (Moustakas, 1994). Dan "sesuatu" dalam penelitian ini yaitu berkaitan dengan tujuan penelitian, dimana subyek memberikan makna SDM sebagai aset intelektual sesuai dengan posisinya dalam Amal Usaha Muhammadiyah.

\section{HASIL DAN PEMBAHASAN}

SDM dalam Universitas Muhamamdiyah Maluku Utara (UMMU) terbagi menjadi empat bagian, yaitu Badan Pembina Harian (BPH), dosen, tenaga kependidikan dan mahasiswa. Pertama, BPH sesuai Pedoman Pimpinan Pusat Muhammadiyah Nomor 02/PED/1.0/B/2012 tentang Perguruan Tinggi Muhammadiyah dibentuk oleh Pimpinan Pusat Muhammadiyah yang berfungsi untuk memberikan arah dan pertimbangan kepada Perguruan Tinggi Muhammadiyah (PTM) dalam pengelolaan PTM, menyusun rancangan pendapatan dan belanja tahunan, menyusun RIP dan statuta, dan membuat laporan kepada Pimpinan Pusat Muhammadiyah. Selain itu, BPH juga berwenang mengangkat dan memberhentikan dosen dan tenaga kependidikan, melaksanakan pembinaan dan pengawasan penyelenggaraan PTM, serta melakukan pembinaan dan pengembangan Al-Islam dan Kemuhamamdiyaan. Kedua, dosen menurut Undang-undang Republik Indonesia, Nomor 14 Tahun 2005 merupakan pendidik profesional dan ilmuwan dengan tugas utama mentransformasikan, mengembangkan dan menyebarluaskan 
ilmu pengetahuan, teknologi dan seni melalui pendidikan, penelitian, dan pengabdian kepada masyarakat. Ketiga, tenaga kependidikan menurut Undang-Undang No. 20 Tahun 2003 merupakan anggota masyarakat yang mengabdikan diri dan diangkat untuk menunjang penyelenggaran pendidikan. Kempat, mahasiswa diungkapkan Hartaji (2012:5) sebagai seseorang yang sedang dalam proses menimba ilmu ataupun dan terdaftar sedang menjalani pendidikan pada salah satu perguruan tinggi baik Akademik, Politeknik, Sekolah Tinggi, Institusi dan Univerisitas. Keempat tersebut memiliki fungsi dan tugas masing-masing, akan tetapi memiliki tujuan yang sama, yaitu mewujudkan cita-cita UMMU dan Muhammadiyah.

UMMU memiliki fungsi sebagai Catur Dharma yaitu: pengembangan ilmu pengetahuan, penelitian, pengabdian pada masyarakat, dan Al-Islam Kemuhammadiyaan. Catur Dharma tersebut tidak saja melekat pada UMMU, tetapi juga terhadap seluruh Amal Usaha Muhammadiyah di Indonesia. Inilah ciri khas untuk membedakan Amal Usaha Muhammadiyah dengan Perguruan Tinggi Negeri maupun Perguruan Tinggi Swasta lainnya. Istilah Amal Usaha memiliki makna tersendiri bagi pengelola UMMU, sebagaimana diungkapkan Pak Kasman:

"Istilah Amal Usaha Muhamadiyah ditujukan pada sekolah-sekolah Muhamadiyah, baik dari TK-Perguruan Tinggi, Rumah Sakait/Klinik, dll. Amal Usaha juga memiliki dua dimensi yaitu "amal dan usaha" sebenarnya ini tergantung orang menafsirkan, tetapi yang harus diperhatikan adalah amalnya, karena tanpa amal tidak akan ada usaha. Gerak Amal Muhammadiyah yaitu multi dimensi, tergantung dari sisi mana orang melihat, pada akhirnya ketemu pada satu titik yaitu amal".

Dalam pandangan Berger dan Lucman (1990) sebagai teori konstruksi sosial, ketika menyebut "amal usaha" adalah sekolah-sekolah Muhamadiyah, baik dari TK-Perguruan Tinggi, Rumah Sakit/Klinik, dll. Pandangan pengelola UMMU terhadap "amal usaha" juga menjadi motivasi tersendiri dalam melaksanakan pekerjaan untuk mendapatkan amal disisi Allah SWT. Untuk itu, gerak amal mampu menciptakan keiklasan, kesabaran, serta kepercayaan diri dalam menjalankan amanah yang telah dipercayakan kepadanya.

UMMU memiliki tanggung jawab untuk mewujudkan apa yang menjadi citacita Muhammadiyah yaitu mewujudkan masyarakat Islam yang sebenar-benarnya. Artinya, dalam pelayanan pendidikan UMMU tidak sekedar mengajarkan ilmu yang berkaitan dengan jurusan yang dipelajari mahasiswa tetapi juga menjalankan amanah yang telah diamanahkan Muhammadiyah, sehingga mampu mencetak mahasiswa yang cerdas secara emosional, intelektual dan spiritual. Oleh sebab itu, SDM mempunyai peran sangat penting dalam mewujudkan cita-cita tersebut. Karena tanpa SDM hal tersebut mustahil untuk diwujudkan, sebagaimana diungkapkan Pak Kasman yaitu: 
"SDM mempunyai peran yang sangat penting dalam mewujudkan apa yang menjadi cita-cita UMMU bahkan Muhammadiyah. Karena dengan kualifikasi bidang ilmu yang mereka miliki, UMMU dapat mencetak sarjanasarjana yang tidak hanya cerdas secara intelektual, tetapi juga emosional dan spiritual".

Pak Djunaidi menambahkan bahwa:

"SDM merupakan yang paling terpenting, bila dibandingkan dengan gedung, dll, karena sejak UMMU didirikan sebagai syarat utamanya adalah SDM bukan gedung, dll".

Dari pernyataan yang di atas telah menggambarkan SDM manusia merupakan motor penggerak UMMU, dimana ketika UMMU didirikan, sekarang dan dimasa yang akan datang.

Dalam pengembangan pendidikan, UMMU yang terletak di timur Indonesia tentu memiliki tantangan tersendiri, mulai dari kondisi budaya, fasilitas, serta SDM. Untuk menjadi SDM yang dapat menyebarkan ilmu serta menyebarkan dakwah, tentu harus sesuai standar kualifikasi sebagaimana diungkapkan Pak Ishak:

"Syarat untuk menjadi tenaga pengajar yaitu harus memiliki kompetensi sesuai standar yaitu Starata Dua (S2) atau Starata Tiga (S3) serta wajib untuk memiliki pemahaman Islam yang baik dan mampu menjalankannya. Hal yang sama juga dilakukan untuk penerimaan tenaga kependidikan. Karena UMMU tidak saja mencetak sarjana yang cerdas intelektual, tetapi juga emosional dan spiritual. Sehingga dalam seleksi tenaga dosen dan tenaga kependidikan, kami tidak hanya menyeleksi kompetensi keahlian yang dimiliki, tetapi juga Keislaman dan Kemuhammadiyaan”.

UMMU menyadari peran SDM sebagai penyebar ilmu serta penyebar dakwah, sehingga difasilitasi dosen yang masih Starata Satu (S1) untuk melanjutkan studi ke Statara Dua (S2), bahkan sampai ke jenjang Starata Tiga (S3). Untuk pemahaman Islam serta Kemuhammadiyaan dilakukan pembinaan khusus mulai dari pengajian dwi mingguan yang bekerja sama dengan Pimpinan Wilayah Maluku Utara, serta dilakukan Baitul Arqam Pimpinan khusus untuk Badan Pembina Harian (BPH), dosen dan pegawai. Sementara mahasiswa dilakukan pembinaan yang berkaitan dengan pengembangan minat dan bakat, pelatihan kemimpinan, serta Taman Baca tulis Al-Quran. Hal tersebut dilakukan untuk mewujudkan cita-cita UMMU serta Muhamamdiyah dalam hal ini mewujudkan masyarakat Islam yang sebenarbenarnya.Olehnya itu, dalam proses penyebaran ilmu dilakukan dalam proses belajar mengajar, yang dimana ada perpaduan ilmu umum dan agama. Bukan saling dipisahkan, sebagaimana yang terjadi selama ini, tetapi proses belajar mengajar 
setiap materi harus dihubungkan dengan ilmu agama. Sebagaimana diungkapkan Pak Hasanuddin:

"Dalam proses belajar mengajar dosen dituntut memadukan ilmu yang diajarkan dengan nilai-nilai Islam (agama).

Dari pernyataan tersebut di atas menempatkan SDM tidak sakadar sebagai agen penyebar ilmu, tetapi juga sebagai agen penggerak dakwah. Hal ini dilakukan untuk membentuk karakter mahasiswa menjadi pribadi-pribadi yang peduli terhadap masalah-masalah sosial, serta menjadi agen perubahan bagi keluarga, masyarakat dan bangsa dan negara.

SDM juga memiliki peran sebagai penggerak dakwah, hal tersebut tidak serta merta harus naik ke podium untuk berceramah, mengisi materi ceramah, dll. Akan tetapi sebagai penggerak dakwah dalam hal ini berkaitan dengan nilai-nilai spiritual, sosial. Sebagaimana yang terkenal slogan di Muhamamdiyah yaitu Al-Maun dan amar ma'ruf nahi munkar, seperti menyantuni anak yatim, fakir miskin dan selalu melakukan hal yang baik dan mencegah yang buruk.

Konstribusi SDM bagi perkembanagan UMMU merupakan aset yang sangat potensial bagi perkembangannya. Karena aset sesuai Financial Accounting Standar Board (FASB) sebagaimana diterjemahkan Suwarjono (2006:252) suatu aset dapat dikatakan aset ketika dapat memberikan konstribusi dimasa yang akan datang. Konstribusi yang diberikan SDM tidak hanya sakadar ekonomi tetapi juga sosial dan spritual. Konstribusi ekonomi dalam hal ini berkaitan dengan pendapatan yang terima oleh UMMU setiap semester, dimana mahasiswa yang terus meningkat. Sementara kontribusi sosial yang terima oleh UMMU adalah kepercayaan publik terhadap keberadaannya di Maluku Utara. Terakhir, konstribusi spritual yang berkaitan dengan perpaduan ilmu pengetahuan umum dan ilmu agama yang mampu menggerakan mahasiswanya menjadi pribadi-pribadi yang menyadari kehadiran Allah SWT disetiap aktivitas kesehariannya. Sehingga Ibu Yana mengatakan:

"Kami sebagai SDM tidak bisa diposisikan sekedar sebagai beban. Tetapi juga harus diposisikan sebagai sumber pendapatan, karna dengan kami UMMU mendapat kepercayaan publik yang dibuktikan dengan mahasiswa yang terus bertambah setiap tahunnya".

Pak Fauji menambahkan:

"SDM dalam pelaporan keuangan ditempatkan sebagai beban. Untuk itu, kami juga punya laporan perkembangan UMMU, yang itu menempatkan SDM sebagai faktor terpenting. Kami sangat menyadari hal tersebut sangatlah tidak adil bila harus menempatkan mereka sebagai beban seperti beban listrik, sehingga laporan perkembangan UMMU merupakan pengakuan kami terhadap keberadaan SDM sebagai aset". 
Dari pernyataan di atas dapat disimpulkan bahwa SDM tidak hanya sekedar sebagai beban, tetapi juga sebagai sumber pendapatan bagi UMMU. Hal tersebut dikarenakan peran SDM yang mampu melahirkan sarjana-sarjana yang dapat memenuhi kebutuhan Pemerintah Provinsi Maluku Utara maupun pihak swasta. Sehingga masyarakat Maluku Utara menjadikan UMMU sebagai pilihan ketika anak-anak mereka akan melanjutkan studi pada perguruan tinggi. Selanjutnya, apa yang disampaikan Pak Fauji telah menempatkan SDM tidak lagi sebagai beban sebagaimana dalam laporan keuangan tetapi juga diakui sebagai aset dalam laporan perkembangan UMMU.

Laporan keuangan tidak hanya bersifat kuantitatif (angka-angka), tetapi juga dapat dijelaskan secara kualitatif (lihat Triyuwono, 2012 dan Mulawarman, 2011). Karena ketika akuntansi hanyalah bersifat kuantitatif, maka yang bersifat kualitatif tidak bisa akan diakui. Untuk itu, laporan keuangan UMMU dan laporan perkembangan UMMU merupakan perpaduan kuatitatif dan kualitatif yang menempatkan SDM sebagai beban dan juga sebagai aset.

Dalam pencatatan akuntansi, SDM diposisikan sebagai beban bukan sebagai aset. Hal tersebut disebabkan perusahaan harus memberikan gaji pendidikan dan pelatihan. Akan tetapi ketika sebuah perusahaan tanpa campur tangan SDM, maka perusahaan tersebut tidak bisa beroperasi. Harahap (2011:423) berkesimpulan tanpa SDM, perusahaan tidak akan bisa menghasilkan laba atau menambah nilainya sendiri. Karena SDM yang mengelola suatu perusahaan dan SDM menciptkan nilai tambah tersebut. Di luar SDM adalah aktiva pasif yang tidak bisa berbuat apa-apa tanpa investasi kebijakan SDM.

\section{SIMPULAN}

Amal Usaha Muhammadiyah merupakan tempat untuk menyebarkan ilmu dan dakwah. Tentu, SDM merupakan motor penggerak untuk mewujudkan citacita UMMU bahkan Muhammadiyah, yaitu mewujudkan masyarakat Islam yang sebenar-benarnya. Di mana masyarakat Islam yang sebenar-benarnya adalah masyarakat yang selalu beramar ma'ruf nahi munkar, sehingga tidak terjadi lagi kebodohan, kemiskinan, penindasan, dll.

SDM merupakan aset intelektual yang diposisikan dalam beberapa katagori, yaitu: Pertama, sebagai penyebar ilmu yaitu dengan keahlian yang dimilikinya, SDM mampu menyebarkan nilai-nilai sesuai dengan pekembangan zaman. Kedua, SDM sebagai penggerak dakwah, hal ini berkaitan amar ma'ruf nahi munkar dimana SDM harus mampu memadukan ilmu pengetahuan umum dan agama, agar terwujudnya mahasiswa yang cerdas secara intelektual, emosional dan spritual. Ketiga, SDM sebagai sumber pendapatan, yaitu berkaitan dengan poin pertama dan kedua sehingga mampu menumbuhkan kepercayaan publik dan membuahkan hasil yang positif yang dibuktikan dengan mahasiswa terus meningkat. Keempat, 
SDM sebagai beban, yaitu berkaitan dengan UMMU yang diwajibkan untuk membayar gaji, membiayai pelatihan dan pendidikan.

Dalam pelaporan, SDM diposisikan sebagai beban dalam laporan keuangan UMMU dan juga diakui sebagai aset dalam laporan perkembangan UMMU. Artinya terjadi perpaduan pengakuan SDM di UMMU sebagai beban dan sebagai aset intelektual secara kuantitaif maupun kualitaif. Dengan demikian SDM tidak dapat dikatagorikan sebagai beban, sebagaimana penjelasan sebelumnya.

Hasil penelitian ini telah menjembatani terkait perdebatan posisi SDM sebagai aset atau beban dikalangan akedemisi maupun praktisi akuntansi. Hasil penelitian ini membuktikan bahwa SDM dapat dikatakan sebagai aset, juga sebagai beban bagi perusahaan. Karena SDM merupakan penggerak organisasi, yaitu berkaitan dengan mewujudkan cita-cita perusahaan baik dalam bentuk ekonomi, sosial dan spritual, sehingga perusahaan juga harus mengeluarkan biaya terkait gaji, pelatihan dan pendidikan untuk meningkatkan kualitasnya. Dapat disimpulkan bahwa SDM merupakan aset intelektual yang berfungsi sebagai penyebar ilmu, penggerak dakwah, sumber pendapatan dan beban bagi perusahaan.

Penelitian ini dilakukan hanya sebatas mengungkap SDM sebagai aset intelektual. Penelitian ini memandang perlu dilakukan pendalaman terkait nilai yang berikan SDM terhadap tempat dimana ia bekerja. Artinya, SDM dapat dikaji dalam pandangan akuntansi yang lebih spesifik, contonya akuntansi sumber daya manusia atau sejenisnya. Sehingga mampu menciptakan teori akuntansi sumber daya manusia yang lebih membumi dan mudah diaplikasikan oleh pemakainya.

\section{DAFTAR PUSTAKA}

Audifax. 2008. Research. Sebuah Pengantar untuk "Mencari Ulang” Metodologi Penelitian dalam Psikologi. Jalasutra.Yogyakarta dan Bandung.

Taylor, S., dan Bogdan, R. 1993. Doing Field Research: Pratice and Meta-theory in Conterpoint. Jurnal of Management and Accounting Research.

Denzin, N.K., dan Lincoln, Y.S. 2009. Handbook of Qualitative Research. Sage Publication,California-USA.

Groenewald, T. 2004. A Phenomenological Research Design Illustrated. International Journal of Qualitative Methods, 3 (1) April.

Ikatan Akuntansi Indonesia. 2009. Standar Akuntansi Keuangan. Jakarta: Salemba Empat.

Lank, I. 1997. Leveraging Invisible Assets: The Human Factor. Long Range Planning 3(3): 406-412

Luayyi. 2012. Makna Aset dan Pelaporan Pondok Pasantren. Tesis Program Magister Akuntansi, Program Pasca Sarjana Fakultas Ekonomi dan Bisnis Universitas Brawijaya.

Mulawarman, A.D. 2011. Akuntansi Syari'ah. Teori Konsep dan Laporan Keuangan. Bani Hasim Press dan E Publisisng Kompany, Malang dan Jakarta.

Moleong, L.J. 2006. Metode Penelitian Kualitatif. Bandung: ROSDA.

Moustakas, C. 1994. Phenomelogical Reseaech Methods, Sage Publications, USA.

El-Muhasaba, Vol. 7, No 1, Januari 2016 
Pedoman Pimpinan Pusat Muhammadiyah Nomor 02/PED/1.0/B/2012 tentang Perguruan Tinggi Muhammadiyah.

Rodhe, J.G., dkk. 1976. Human Resorce Accounting: A Critical Assemnt, Issue. Industri Relationt: A Journal Of Economy And Society 15(1): 13-25.

Singh, M. 2009. Human Resource Accounting Chellenge For Accountant. ISSN-09742832, II (5): 440-442.

Suwarjono. 2006. Teori Akuntansi Perakayasaan Laporan Keuangan. Edisi Ketiga. Yogyakarta: BPFE.

Sukuharsono, E.G. 2006. Alternatif Riset Kualitatif Sains Akuntansi: Biografi, Phenomenologi, Grounded Teory, Etrnografis Kritis, dan Studi Kasus, Analisis Makro dan Mikro. BPFE Universitas Brawijaya, Malang: 230-245.

Setiabudi, H.Y., dan Triyuwono, I. 2002. Akuntansi dan Ekuitas, dalam Narasi Kapitalisme, Sosialisme, dan Islam. Jakarta: Salemba Empat.

Smith, Jonathan, A., Flowers, P., and Larkin, M. 2009. Interpretative phenomenological analysis: Theory, method and research.Sage, Los Angeles, London, New Delhi, Singapore, Washington.

Smith, Jonathan, A. (ed.). 2009. Psikologi kualitatif: Panduan praktis metode riset. Terjemahan dari Qualitative Psychology A Practical Guide to Research Method. Yogyakarta: Pustaka Pelajar.

Triyuwono, I. 2012. Akuntansi Syariah. Perspektif, Metodologi, dan Teori. Edisi Kedua. Jakarta: Rajawali Pers.

Undang-Undang Republik Indonesia. Nomor Tahun 2003 tentang Sistem Pendidikan.

Undang-undang Republik Indonesia. Nomor 14 Tahun 2005 tentang Guru dan Dosen.

Widati, S. 2012. Makna Aset Persyarikatan Aisyiyah dengan Nilai al Quran dan Tao Te Ching sebagai Alat Dekonstruksi. Thesis Program Magister Akuntansi. Program Pasca Sarjana Fakultas Ekonomi dan Bisnis Universitas Brawijaya.

Wulandari, P.P. 2011. Mengungkap Akuntansi Pemain Sepak Bola sebagai Aset Klub. Tesis Program Magister Akuntansi. Program Pasca Sarjana Fakultas Ekonomi dan Bisnis Universitas Brawijaya.

Welman, C.J., dan Kluger, S.J. 1999. Research Methodology for the Business and Administration Science, International Thomson, Johannesburg.

Yanping, J.C., dan Yang, R.W. 2005. Research On Accounting Of Human Resoources Devolopment. China-USA Business Review 4 (4):1537-1514. 